DOI: $10.2478 /$ rpp-2018-0001

Doctor of Science in Pedagogy, Senior Researcher, NATALIYA AVSHENYUK Institute of Pedagogical Education and Adult Education, the NAPS of Ukraine Address: 9 M. Berlynskyi St., Kyiv, 04060, Ukraine E-mail: nataliya.avshenyuk@gmail.com

\title{
USA EDUCATION POLICY IN TRANSNATIONALIZATION OF HIGHER EDUCATION
}

\begin{abstract}
The analysis of American experience of higher education transnationalization, as well as influence of these processes on various spheres of social development has been done. The main factor is the desire to improve the quality of higher education national system, which leads to positive competition between local and foreign universities and serves as an important incentive for improving the quality of educational services. The obtained results testify that over the past decades the higher education transnationalization has become a subject of state "soft power" policy aimed at addressing specific internal political, social and financial problems. The "soft power" policy concept (by J. Nye) defines it as the ability of a country to get the desired issue by self-attractiveness rather than conquest power or money. The key of "soft power" is the image of the state, which is formed and managed not only by the government, but the citizens themselves, the country as a whole, including its history, achievements, culture, etc. The study leads to the conclusion that higher education transnationalization in the United States is a result of active international marketing activities of universities, as well as targeted state economic, political and information support. The prognostic potential of the conducted scientific research enables the concept development of Ukrainian higher education integration into the world educational space on the basis of constructive ideas of foreign experience consideration at the state and institutional levels.

Keywords: educational policy, transnational higher education, "soft power" policy, national brand in education, export of educational services, exchange programmes, USA.
\end{abstract}

\section{INTRODUCTION}

The original conceptual ideas of the article are as follows: higher education ensures future development of the country through the formation of high-quality human (education, health) and social (culture, civil society) capital; higher education is a key factor and a necessary condition for the development of any government state, since during the last decades it has established itself as a powerful branch of the economy, on the successful functioning of which depends the state of social progress as a whole; human capital in economic systems of modern countries is of great importance for ensuring the national competitiveness, because the advantages of the economy and the possibility of its modernization are determined by accumulated and realized human capital.

The expansion of international exports of educational services over the last thirty years has become one of the most important priorities of the state policy of developed English-speaking countries, first of all, the United States. In our opinion, such expansion is due to the increased use of the "soft power" influence of the country that gained momentum in the second half of the 20th century and continued at the beginning of the 21 st century. This process is conditioned by several factors, namely: 
- training of specialists for foreign countries is to facilitate the realization of the geopolitical and economic interests of the native ones;

- training of specialists for foreign countries becomes one of the most profitable issue of export;

- desire to attract foreign students encourages the governments of exporting countries to reform the training system of specialists, taking into account the requirements of the world labour market, to improve the quality of higher education, to develop new curricula and courses with the implementation of the international component, which ensures the graduates to work in the conditions of the global economy, and the transformation of national universities into international scientific and educational complexes;

- desire of educational-exporting countries to use the best foreign students for the development of domestic economy and science.

\section{THE AIM OF THE STUDY}

Analysis of USA educational and political experience will allow higher education managers in Ukraine to evaluate critically the advantages and disadvantages of existing strategies and develop own policy of higher education transnationalization in order to ensure sustainable development of society based on expanding each citizen's ability to obtain high-quality, competitive higher education and professional qualifications.

\section{THEORETICAL FRAMEWORK AND RESEARCH METHODS}

The author of the "soft power" concept, a political scientist from Harvard University $\mathrm{J}$. Nye defines it as the ability to get the desired issue by attractiveness rather than conquest power or money (Nye, 1990). The phenomenon "soft power" as a means of influence of one states to others existed almost always, but it significance increased in the 20th century. The key of "soft power" is the image of the state, which: a) is not static - it can change, and sometimes, even in one moment can be lost; b) is not always subject to the purposeful formation and management, because its carrier is not only the government, but the citizens themselves, the country as a whole, including its history, achievements, culture, etc.

At the same time, "soft power" is far from related to the size, economic or military power of the state. A country can, for example, be the leader in: the average life expectancy of its citizens; the level of wages and pensions; the ratings of doing business; the reliability of the national currency; environmental standards; the quality and availability of education; the existence of the state without wars and disasters; and other parameters that shape credibility and reputation of the country. According to the country image, the brand may be a set of characteristics that create a unique perception of the country state. Powerful positive image of the state stimulates attracting investments, increasing exports and the flow of tourists and highly skilled professionals and, in general, contributes to sustainable development of the country. In the era of growing global competition in the external and internal markets of the state, there is a strong need for the management of counties' brand, its development and control (Fetscherin, 2010). In this manner, the purposeful formation of the country brand is seen as an instrument of effective interaction and promotion of national interests at the world level.

The study has shown that in the field of higher education, the national brand and the level of its formation, is estimated as the ability of the country to attract as many foreign students as possible, to establish educational exchanges and to create high-quality universities. But "soft power" is not only the country image, but also the provision of assistance to other states on a bilateral basis, or in other words, the promotion of international 
development. The analysis of "soft power" instruments of influence in the field of higher education and science has proved that transnational education plays a key role in this process. After all, the "soft power" policy of the developed countries in this area is very diverse: it includes many tools and practices, different in scope of audience and areas of cooperation.

\section{RESULTS}

In the experience of foreign countries you can find many examples of work with different target groups (schoolchildren, students, parents, teachers, scientists, young researchers, heads of educational and scientific institutions) at different levels of education (school, higher, postgraduate), the involvement of local educational and scientific organizations. Special attention is paid to the development of interinstitutional cooperation: support of inter-university contacts, cooperation of companies, joint research of partner countries, creation of scientific networks and joint universities (Lazutina, Nagornov, Rakhmangulov, Sakharov, \& Shelepov, 2014). The most common tool for the development of scientific and business partnerships is the transnational individual mobility programs for teachers, scholars and students.

There is no doubt that, central to the country's "soft power" policy is the development of domestic educational services export. Countries are seeking to coordinate their actions in this direction by creating a unified system for attracting foreign students. Important components of such system are information policy (dissemination of information about educational institutions of the "soft power" country) and actions to improve quality of the national education system, in particular the creation of new educational programs. Increasing the attractiveness of educational system of the country-exporter is also important as it involves the process of adaptation to the general international tendencies and local national peculiarities of the education development both countries-"soft power" exporters and countries-importers). The mutual process of educational systems convergence is usually organized through negotiation, conclusion of agreements (for example, recognition of diplomas etc.), as well as taking into account peculiarities (results of national examinations, systems of assessment in national educational institutions etc.) during the implementation of educational and scholarship programs and, in general, development of educational services export (Lazutina, Nagornov, Rakhmangulov, Sakharov, \& Shelepov, 2014). In addition to regular programs (academic exchanges, scholarships etc.), flexible tools are used to address local relevant issues. For example, the training of "educational agents" - the staff of universities promoting the image of the country abroad, which is widely used by Great Britain.

Certain thing, an effective "soft power" policy is characterized mostly by a number of features. The first distinguishing feature is the presence of institutions that provide stability of the "soft power" strategy, the consistency and regularity of the country's actions. Undoubtedly, the ideal model is a form that allows solving several problems and implementing simultaneously different policy areas: language support and promotion; the development of cultural ties; the promotion of educational services export etc. An example of a multifunctional institution can be the British Council of the Great Britain, working simultaneously in the field of education, culture, language learning (British Council, 2015).

Similarly, the second characteristic of the integrated "soft power" policy is the diversification of target groups. The strategy should aim at working with government departments, institutes, companies and individual citizens (schoolchildren, students, teachers and academics). Work with the latter can be carried out through mobility programs, exchanges, grants in the field of education, culture, science. The country's actions at the institutional level are usually aimed at working with schools, universities, non-governmental educational institutions, through initiation of negotiations, grant programs, networking of educational 
institutions, implementation of joint projects, etc. Interaction at the level of ministries and departments can be done by concluding agreements (general, sectoral), holding joint working groups, etc. Critically important for the coherent and consistent operation of all elements of the "soft power" system is the regulatory framework that provides transparency and resilience of the "soft power" policy in partner countries (agreements at the government / departmental level, between institutions and organizations), as well as favourable conditions for carrying out individual actions (for example, simplifying the visa regime for implementation of mobility programs) (National Archives, 2002).

However, the system of informing and marketing support is necessary for ensuring openness and forming a positive image of the country in the global educational space. Coordination mechanisms are also needed to ensure coherence of all elements of the "soft power" strategy. This function, as a rule, is performed by funds regulating work with nongovernmental educational organizations, networks of educational institutions, bilateral commissions or councils.

Taking into account the above mentioned, the governments of countries-exporters provide serious support to their universities, including financial ones, in order to attract foreign students. We share the opinion of the researchers that attracting a significant number of foreign students to the higher education system of developed English-speaking countries is primarily the result of the active international marketing activities of universities, as well as targeted state economic, political and information support.

Let's consider in detail examples of the "soft power" policy application in the field of higher education and science in the United States.

Obviously, the United States has always had a significant "soft power", as many people in the world are impressed by the American idea of personal freedom, equality of opportunity, the American way of life, mass culture, economic achievements. Today, the US remains the only country in the world with a practice of global goal-setting. American foreign policy is designed to ensure global leadership of the United States, and US foreign policy agencies, as stated in the Budget Law, in practice realize this task. The US State Department sees the foreign policy main mission as ensuring freedom for the benefit of the American people and the international community through the creation and development of a democratic, secure and prosperous world, composed of well-governed states that meet the needs of their citizens, contribute to poverty reduction and conduct responsible policies within the international system (U.S. Department of State, 2014). As you can see, the mission is formulated as a policy of "soft power", and its cornerstone is the idea of protecting the values of democracy and freedom.

It should be noted, that in 1961 the US Agency for International Development was set up to promote the country's "soft power" methods in accordance with the "Foreign Assistance Act", bringing together the various foreign policy programs of the country (U.S. Agency for International Development, 1961). Among the key objectives of the Agency, cooperation in the field of education, scientific, technical and innovation cooperation through programs within the ACIE, USAID, as well as through some non-governmental organizations, such as CIEE, has been identified. The above-mentioned cooperation is based on educational and scientific exchanges and programs that allow the attraction of foreign scientific personnel to the United States (U.S. Agency for International Development, 2018).

The study leads to the conclusion that the most widespread and universal direction of the "soft power" policy of the United States since 2010 is still transnational educational and scientific programs, including exchange ones, in particular: 
- Fulbright Program for foreign students, enabling young people to study or research in the United States for one year or more. There is also a direction for English language teachers, which provide opportunities for young teachers from all over the world to improve their teaching methods, English language proficiency and expand their knowledge of the United States by completing a nine-month course of study without a degree. In addition to studying, scholarship students teach their native language to students at the host university.

- Hubert H. Humphrey Program - a one-year scholarship program designed for young professionals with leadership qualities to demonstrate their commitment to benefit society and can simultaneously benefit from an independently tailored program of study at leading American universities.

-Edmund S. Muskie Program for university graduates, which provides an opportunity to study in the United States for a Master's degree.

- Program of the Benjamin Franklin Transatlantic Fellows Summer Institute designed for students from Central Asia aged 16 to 18 . The purpose of the program is to promote the strengthening of relations between representatives of the younger generation and to teach them jointly solve the global problems of the 21 st century.

- English Language Access Program, the purpose of which is to provide young people from poor families with an opportunity to learn English and develop their leadership skills through studying the foundations of the US culture and civic engagement, as well as democratic values.

- Future Leaders Exchange program to establish friendship between the peoples of the United States and Eurasia.

- The Global UGRAD Program allows undergraduate elementary students to undergo an academic year without a degree in US universities and colleges in accounting, agriculture, business, computer science, criminal justice, economy, education, management, environment, hotel business, international relations, journalism and media, law, political science, psychology and sociology.

However, in the beginning of the 21st century the rapid development of the global market for educational services has raised the problem of ensuring the quality of their provision on a transnational basis, which resulted in an intensive rethinking of the organizational and pedagogical principles of education transnationalization in developed English-speaking countries. The need to maintain competitiveness in the international educational market has prompted the US government to introduce a number of initiatives, among which the Education Development Strategy "Succeeding Globally Through International Education and Engagement 2012-2016" developed in 2012 by the US Department of Education (U.S. Department of Education, 2012).

The analysis of the document showed that the strategy is aimed at implementation of two important tasks:

1) improving the quality of education in the United States;

2) promoting the priority goals of the country's foreign policy by: ensuring a high quality of higher education for all students; development of global competence; international benchmarking in education and application of the experience of other countries; improving educational diplomacy and interaction with other countries and international organizations.

The strategy reflects the actual direction of the government on young people effective learning for a globalized world and cooperation with other countries in order to improve the education quality based on their experiences and implementing best practices. This document represents a holistic and systematic approach to international activities, 
reflected in its goals and objectives. Transnationalization of higher education in the United States is aimed at developing mechanisms for managing this area, due to the lack of government strategies for university management, the superiority of private initiatives in the existing mechanisms of university management, the dependence of transnational higher education strategies development on the particular leadership of universities, complicated schemes of international activities financing, mainly based on self-financing.

\section{CONCLUSIONS}

Summing up the analysis of American experience of higher education transnationalization, as well as influence of these processes on various spheres of social development, we can state that one of the main factors of the mentioned process is, first of all, the desire to improve the quality of higher education national system. This, in turn, leads to positive competition between local and foreign universities and serves as an important incentive for improving the quality of educational services. The obtained results testify that over the past decades the higher education transnationalization has become a subject of state "soft power" policy aimed at addressing specific internal political, social and financial problems. Summarizing the study, we can conclude that the higher education transnationalization in the United States is a result, first of all, of active international marketing activities of universities, as well as targeted state economic, political and information support. The prognostic potential of the conducted scientific research enables the development of the concepts of Ukrainian higher education integration into the world educational space on the basis of constructive ideas of foreign experience consideration at the state and institutional levels.

\section{REFERENCES}

1. British Council. (2015). Corporate reports and documents. Retrieved from http://www.britishcouncil.org/organisation/how-we-work/reports-documents.

2. Fetscherin, M. (2010). The determinants and measurement of a country brand: the country brand strength index. International Marketing Review, 27 (4), 466-479.

3. Lazutina, I. V., Nagornov, V. A., Rakhmangulov, M. R., Sakharov, A. G., \& Shelepov, A. V. (2014). Sistematizatsiia luchshikh zarubezhnykh podkhodov k realizatsii politiki "miagkoi sily". Vestnik mezhdunarodnykh organizatsii, 9 (2), 229-245.

4. National Archives. (2002). International Development Act. Retrieved from http://www.legislation.gov.uk/ukpga/2002/1/contents.

5. Nye, J. (1990). Bound to lead: the changing nature of American power. New York, NY: Basic Books.

6. U.S. Agency for International Development. (1961). The Foreign Assistance Act of 1961. Retrieved from http://pdf.usaid.gov/pdf_docs/ pcaab142.pdf.

7. U.S. Agency for International Development. (2018). Who we are. Retrieved from http://www.usaid.gov/whowe-are.

8. U.S. Department of Education. (2012). Succeeding globally through international education and engagement: U.S. Department of Education international strategy 2012-16. Retrieved from http://www2.ed.gov/about/ inits/ed/internationaled/international-strategy2012-16.pdf.

9. U.S. Department of State. (2014). Bureau of Budget and Planning: Mission. Retrieved from http:/www.state.gov/s/d/rm/index.htm\#mission. 